\title{
Chemical and Structural Characterization of Poplar and Black Pine Wood Exposed to Short Thermal Modification
}

\section{Kemijska i strukturna obilježja drva topole i crnog bora izloženih kratkotrajnoj toplinskoj modifikaciji}

\author{
Original scientific paper • Izvorni znanstveni rad \\ Received-prispjelo: 8. 6. 2020. \\ Accepted-prihvaćeno: 14. 1. 2021. \\ UDK: $630 * 813.4 ; 674 * 031.32 ; 674 * 032.475 .444$ \\ https://doi.org/10.5552/drvind.2021.2026
}

(C) 2021 by the author(s).

Licensee Faculty of Forestry and Wood Technology, University of Zagreb. This article is an open access article distributed under the terms and conditions of the

Creative Commons Attribution (CC BY) license.

\begin{abstract}
In this study, poplar and black pine wood was exposed to short thermal treatments, aiming to improve some crucial properties. Using wet chemical analyses and Fourier-transform infrared spectroscopy (FT-IR), the influence of these treatments on the chemical composition of the modified species was investigated, as well as on the wood structure, using scanning electron microscopy. With the increase of heat treatment intensity, a mass loss of both species was recorded, attributed to the moisture loss and degradation of volatile compounds, as well as thermally less stable components. In the first treatment stages, the extractives presented a decrease, whereas with the duration and temperature increase, new extractives were formed. Lignin increased its network through ramification, especially at $200{ }^{\circ} \mathrm{C}$, while holocellulose was found lower in all modified wood categories of both species than in unmodified wood due to the intense decomposition of hemicelluloses. The findings of FT-IR analyses were in line with the chemical analysis results. The thermal modification process made wood materials more hydrophobic and dimensionally stable, providing protection against decomposing factors. At the same time, they were not intensively thermo-degraded, which increased their utilization perspectives and application range as solid wood of enhanced properties, or as wood particles/fibers participating as raw materials in wood-based composite products, wood-polymers composites etc., enhancing their materials compatibility, properties and performance.
\end{abstract}

Keywords: cellulose; chemical composition; FTIR; lignin; thermal treatment; wood

SAŽETAK • U radu se opisuje istraživanje izlaganja drva topole i crnog bora kratkotrajnim toplinskim tretmanima radi poboljšanja nekih njihovih ključnih svojstava. Utjecaj tih postupaka na kemijski sastav modificiranih vrsta drva istražen je primjenom mokre kemijske analize i Fourierove transformirane infracrvene spektroskopije (FT-IR), a utjecaj na strukturu drva određen je uz pomoć pretražnoga elektronskog mikroskopa. Povećanjem intenziteta toplinskog tretmana zabilježen je gubitak mase obiju vrsta drva koji je pripisan gubitku vode te razgradnji hlapljivih i toplinski nestabilnih spojeva. U prvim fazama tretmana smanjio se udio ekstraktiva, dok su se s produljenjem tretmana i povećanjem temperature stvarali novi ekstraktivi. Lignin je povećao svoju umreženost razgranjivanjem, posebno na $200{ }^{\circ} \mathrm{C}$, dok je udio holoceluloze bio manji u modificiranome nego u nemodifici-

\footnotetext{
${ }^{1}$ Author is researcher at Aristotle University of Thessaloniki, Faculty of Forestry and Natural Environment, Department of Harvesting and Technology of Forest Products, Thessaloniki, Greece.
} 
ranom drvu, i to zbog intenzivnog razlaganja hemiceluloze. Rezultati FT-IR analize u skladu su s rezultatima kemijske analize. Postupkom toplinske modifikacije drvo je postalo hidrofobnije, dimenzijski stabilnije i zaštićeno od čimbenika razgradnje, ali istodobno nije odviše toplinski razgrađeno, čime su se povećale mogućnosti njegove uporabe i proširila područja primjene kao masivnog drva poboljšanih svojstava ili kao sirovine za kompozitne materijale koja pridonosi njihovoj boljoj kompatibilnosti, svojstvima i performansama.

Ključne riječi: celuloza; kemijski sastav; FT-IR; lignin; toplinski tretman; drvo

\section{INTRODUCTION 1. UVOD}

When heating wood, during the heat modification process, in an attempt to improve some of its drawbacks, bound water is lost and some of the extracts evaporate (flammable volatiles), some decompose, some new ones are produced and some may be left intact (Wang et al., 2018; Esteves and Pereira, 2008). The first to be lost during treatment are the volatile extracts, such as volatile terpenes, fouraniokarvoxylaldehyde, acetic acid, 2-propane, hydrocarbons, fatty acids, steroids, lactones and other derivatives from the thermal degradation of the wood components (Kocaefe et al., 2008), while at the same time, anhydrous and phenolic components appear in the wood mass (Esteves and Pereira, 2008). Resin acids, fats and waxes tend to move to the surface of the wood as the temperature approaches $200{ }^{\circ} \mathrm{C}$ and almost disappear with further increase. When the volatile extracts are removed, the $\mathrm{pH}$ of wood decreases (Gündüz and Aydemir, 2009).

The degree and order of degradation of cell wall components is a matter of many parameters, mainly depending on the species, heating temperature, chamber atmosphere, moisture content, etc. Upon thermal modification, a series of chemical reactions takes place simultaneously, combining endothermic and exothermic reactions, making the determination of the starting temperatures for the different reactions almost impossible. Reaction analysis becomes furthermore complicated by the interactions between the different components and between the components and the chamber atmosphere (Hill, 2006; Johansson, 2008).

Thermal modification in the early stages may alter the amount of volatile extracts. In hardwoods, mainly aldehydes (pentanal, hexanal, furfural), carboxylic acids (acetic acid), esters, ketones, aliphatic and aromatic hydrocarbons are recorded, while in softwood species mainly mono-, mix, diterpenes (Peters et al., 2008). The change in the extracts, in terms of acidity, reactivity and hydrophobicity, also affects the behavior of wood in welding, dyeing and other processes (Diouf et al., 2011). Extracts that are usually of low pH also affect the $\mathrm{pH}$ of wood, which usually demonstrates a further decrease during treatment due to the production of various organic acids such as low molecular weight acetic, formic, galacturonic acid derived from hydrolysis and depolymerization carried out on wood (Yao et al., 2010). The acids produced during treatment promote further the decomposition of wood components and are responsible for the loss of mass and the decrease in mechanical strength of wood (Wang et al.,
2018), and especially if they are volatile, it is difficult to evaluate them quantitatively and qualitatively (Gündüz and Aydemir, 2009; Hill, 2006; Peters et al., 2008). Recently, Ozcifci et al. (2018) focused on the investigation of the effects of catalysts $(\mathrm{NaOH}, \mathrm{KOH}$ solutions) on the strength loss, mass loss and chemical structure of heat-treated wood, revealing that potassium hydroxide $(\mathrm{KOH})$ can decrease the degree of strength loss and mass loss of heat-treated wood by reducing the release of acid that leads to thermo-degradation during heat treatment.

During thermal modification, the degree of cellulose polymerization is significantly reduced by increasing the temperature, causing an accelerated degradation. Amorphous or less crystalline cellulose is gradually degraded (Wang et al., 2018). The first derivative of the cellulose decomposition during thermal treatment is levoglucosan and also anhydroglucose, furan, furan derivatives, etc., and they have low hygroscopicity (Yildiz et al., 2006; Rowell et al., 2009; Ates et al., 2010; Tumen et al., 2010; Kamperidou, 2019). Hemicelluloses consist of the most unstable polymeric wood components and produce furfuryl polymers, which are less hygroscopic, as well as methanol, acetic acid and aldehydes and various other volatile heterocyclic components (furans, $\gamma$-valerolactone, etc.) and low molecular weight extractable compounds (Diouf et al., 2011), which tend to act as catalysts of the polysaccharide depolymerization (Tjeerdsma and Militz, 2005; Kamperidou and Barboutis, 2018). As the treatment intensity increases, carbonyl groups are produced due to the esterification occurring in wood when the acids react with hydroxyls (Tjeerdsma and Militz, 2005; Esteves and Pereira, 2008; Rowell et al., 2009). As hemicelluloses degrade, the wood becomes brittle and rigid (Kamperidou and Barboutis, 2017). The hemicelluloses of softwoods (hexoses) are less unstable than those of hardwoods (pentoses), because of the different composition (Esteves et al., 2007; Ahajji et al., 2009). Also, the hardwoods have a higher proportion of hemicelluloses (xylose) than softwoods (mannose and galactose), and hardwood hemicelluloses carry higher percentages of acetylenes than softwoods (Wikberg and Maunu, 2004; Hill, 2006; Ates et al., 2010). The decomposition is more pronounced in the early stages of thermal treatment (Mburu et al., 2007).

Lignin proves to be the most stable component of wood and as the intensity of treatment increases, lignin increases in the mass of wood, trapping some by-products of hemicelluloses decomposition and, as it becomes stronger, its phenolic groups increase as well (Tjeerdsma and Militz, 2005; Gonzalez-Pena et al., 
2009; Diouf et al., 2011). Temperatures below $160{ }^{\circ} \mathrm{C}$ do not cause any changes to lignin, whereas at $170^{\circ} \mathrm{C}$ $-190^{\circ} \mathrm{C}$ the glass transition temperature point appears, where the wood becomes plasticized and easier to be processed. Lignin plasticizing, as well as internal friction, makes the wood break into smaller loads than the unmodified one (especially impact bending strength) (Kol, 2010). The breakdown of lignin macromolecule starts at temperatures above $270{ }^{\circ} \mathrm{C}$, where the gradual cleavage of $\mathrm{C}-\mathrm{C}$ bonds of lignin begins (Mazela et al., 2004). At temperatures below $190^{\circ} \mathrm{C}$, there may be a slight degradation of lignin, generating different phenolic degradation derivatives. At about $220^{\circ} \mathrm{C}$, lignin begins to degrade, with the presence of phenolic compounds (vanillin, coniferaldehyde, syringyl aldehyde), where v-aryl ether linkages begin to degrade (Yildiz and Gumuskaya, 2007). Thermal modification results in changes in aromatic structures and cleaves arylether bonds between lignin-phenylpropane units (Wikberg and Maunu, 2004). As the intensity of the modification increases, both the secondary bonds ( $\mathrm{H}$ and Van der Waals) and natural bonds in the hemicellulose polymer between hemicellulose-cellulose, and covalent bonds between hemicellulose-lignin and new crosslinks appear between lignin molecules and other components, and they do not allow water to penetrate easily in wood, as the $\mathrm{H}$ bonds (Tumen et al., 2010; Diouf et al. 2011). Softwoods lignin seems to be more stable to thermal degradation than lignin of hardwoods. Recently, Gonultas and Candan (2018) determined the influences of the press temperature and the press pressure parameters on the chemical components of the eucalyptus wood. They concluded that the holocellulose and extractives were more affected by heat, with hot water, $1 \% \mathrm{NaOH}$ and EtOH-cyclohexane. According to them, methanol-water solubility of thermally treated wood increased, because of the new substances mainly produced from degradation of the hemicellulose and lignin, while the Klason lignin recorded a significant increase at $180^{\circ} \mathrm{C}$ treatments and a decrease of holocellulose, with a small decrease of $\alpha$-cellulose.

Although, many studies have been carried out dealing with the resulting changes in wood during heat modification, their findings often seem to be contradictory, since the application of treatments under various different conditions, on different wood species and applying different characterization methods, do not provide a clear picture of the changes that occur in the wood mass during the application of high temperatures, while a lack of information in literature has been identified as regards the short duration thermal treatments.

Therefore, in the current work, low cost and energy consumption thermal treatments are selected to be applied (examining two temperature levels and 3 treatment durations, shorter than that typically applied in industrial heat treatments) to the widely available and commercially significant wood species of poplar and black pine, especially for Greece and the whole Europe, whose properties are in imperative need of enhancement and protection especially prior to their ex- posure to environments of high humidity. The changes in chemical composition between the modified and unmodified wood materials are investigated using a combination of the conventional method of wet chemical analyses and Fourier-transform infrared spectroscopy (FT-IR analyses) method, while an attempt to record changes in the structure of the modified species is implemented using stereoscope and scanning electron microscopy (SEM), in order to elucidate the response of the specific wood species mass to thermal treatments, aiming to improve the utilization potential of these wood species in a wider range of applications.

\section{MATERIALS AND METHODS} 2. MATERIJALI I METODE

\subsection{Specimens preparation}

\subsection{Priprema uzoraka}

Boards of poplar (Populus sp.) and black pine (Pinus nigra L.) species of Greek origin (poplar wood was obtained from the Drama region in North Greece and black pine from the Kalampaka region in the central part of Greece) were placed in a conditioned room at a temperature of $(20 \pm 2){ }^{\circ} \mathrm{C}$ and $(60 \pm) 5 \%$ relative humidity for about 8 months and left there to attain the equilibrium moisture content (EMC) of $10.50 \%$ for poplar and $11.44 \%$ for pine wood (ISO 13061-1). The mean density (mass/volume, measured in the above mentioned moisture contents) of poplar was $0.385 \mathrm{~g} /$ $\mathrm{cm}^{3}$ and of pine $0.662 \mathrm{~g} / \mathrm{cm}^{3}$ (ISO 13061-2). The dimensions of the boards of both species prior to the treatments were $35 \mathrm{~mm} \times 70 \mathrm{~mm} \times 400 \mathrm{~mm}$ (with the last to be parallel to grain); they consisted mainly of the part of sapwood, and the sampling method was based on the methodology of ISO 3129.

\subsection{Thermal treatments}

\subsection{Toplinski tretmani}

The treatment of the boards was carried out in a laboratory drying chamber $(800 \mathrm{~mm} \times 500 \mathrm{~mm} \times 600$ $\mathrm{mm})$ at $180{ }^{\circ} \mathrm{C}$ and $200{ }^{\circ} \mathrm{C}$ under atmospheric pressure in the presence of air. The moisture content of the boards was $10.5 \%$ and $11.44 \%$ for poplar and black pine, respectively, when placed in the chamber (10 boards/treatment, chamber preheated to the final temperature). The treatment durations were of 3,5 and 7 hours, counting 15 minutes more for the chamber reheating after the insertion of the samples. In this study, thermal treatments of such short durations are examined for the first time on the studied wood species, according to the literature. They were chosen to keep cost and energy consumption of the treatments at a low level, in order to be easily applied by small industries, using the simple equipment of the drying chamber. Furthermore, the specific durations were selected as they differentiate from the existing literature of thermal treatment processes, thus providing new data.

After thermal treatment, the boards were placed in large desiccators over silica gel to return gradually to ambient conditions. Only defect-free material was selected for testing. 
The mass loss $(M L)$ of the specimens induced by the process of thermal treatment (thermo-degradation) was determined by the oven drying method (e.g. Wang et al., 2018) according to the following Eq. 1:

$$
M L=\left[\frac{\left(M_{0}-M_{1}\right)}{M_{1}}\right] \cdot 100
$$

Where:

ML - Mass loss, $\%$

$M_{0}$ - Initial oven-dry mass of the specimen before thermal treatment, $g$

$M_{1}$ - Oven-dry mass of the same specimen after thermal treatment, $\mathrm{g}$

Thermal treatment of poplar wood under the above mentioned conditions induced mass losses in the range of $11.24 \%-18.88 \%$, of which $10.50 \%$ corresponds to moisture, generated by the drying and thermo-degradation process, whereas thermally-treated black pine wood recorded a little lower mass losses of $10.63 \%-15.25 \%$, of which the $11.44 \%$ refers to moisture content loss. Additionally, the wood of black pine contains a significant amount of resin, and the mass loss could also be partly attributed to the evaporation of the resin during the thermal treatment, as well as other volatile compounds and unstable components (Kamperidou, 2019).

\subsection{Infrared spectroscopy (FT-IR)}

\subsection{Infracrvena spektroskopija (FT-IR)}

Wood powder samples were prepared from all categories of modified and unmodified poplar and black pine, using a rotating-blade "Willey" mill (Thomas Scientific, Swedesboro, USA). The samples were obtained through sieving twice to achieve the appropriate dimensions (fraction between grid apertures of 40-60 mesh).

For the preparation of the samples, $\mathrm{KBr}$ was mixed with wood powder in the ratio of $1 / 200 \mathrm{mg}$ and each sample was ball milled for $20 \mathrm{sec}$ to a very fine powder (Mikro Dismembrator, Sartotius). Then, it was placed in a standardized pellet press having a die suitable to form a pellet of $13 \mathrm{~mm}$ diameter, applying force of about $10 \mathrm{t}$ through vacuum conditions $\left(75 \mathrm{kN} \mathrm{cm}^{-2}\right.$ for $3 \mathrm{~min} / \mathrm{sample})$. A non-finite ATI Mattson-type (Mattson ATI Genesis, Illinois, USA) spectrophotometer was used with spectra in the range of $500 \mathrm{~cm}^{-1}$ $4000 \mathrm{~cm}^{-1}$ and 64 scans.

\subsection{Chemical analyses}

2.4. Kemijska analiza

Wood powder used in the chemical analyses was produced using the above mentioned "Willey" mill equipped with a 40 mesh sieve. The wood powder was sieved keeping the fraction $(0.18 \mathrm{~mm}-0.25 \mathrm{~mm})$. Soxhlet type extractors were used to carry out the extractions. The distilled water used was produced with a GFL 2001/2 distillation apparatus (GFL, Burgwedel, Germany).

Determination of solubility in a mixture of ethanol-toluene was performed on the basis of ASTM D1107-96 using a Soxhlet apparatus. The determination of the total amount of the extracts, soluble in ethanol-toluene mixture, was implemented indirectly through the production of extract-free wood, according to ASTM D1105-96. A least five wood powder samples were used for each type of material and the mean values were calculated.

Holocellulose (cellulose and hemicelluloses) content was quantified by removing lignin from wood powder, which was already free of extracts. Dry wood (atro), free of extracts, with dimensions between 180 and $250 \mu \mathrm{m}$ was used. $10 \mathrm{ml}$ of the chlorine solution of $\mathrm{NaClO}_{2}(25 \%)$ was applied to $1 \mathrm{~g}$ atro wood powder in a water bath set at $70{ }^{\circ} \mathrm{C}$ for 5 hours, making lignin oxidized and cleaved into soluble derivatives, which were removed by extraction, whereby the holocellulose remained as a residue. At the end of this process, the sample was rinsed with cold water until $\mathrm{Cl}_{2}$ was completely removed and placed in a drying chamber. The dry sample was placed in a desiccator and then weighed, and the holocellulose (atro) was quantified as a percentage value of the initial mass of the extractsfree powder sample. For each holocellulose sample obtained after rinsing, the process was repeated till constant mass was achieved. A least two replicates were used for each type of material and the mean values were calculated.

The quantitative determination of lignin was based on the hydrolytic cleavage of polysaccharides with inorganic acids $\left(\mathrm{H}_{2} \mathrm{SO}_{4}\right.$ in concentration of $\left.72 \%\right)$, which resulted in the depolymerization and removal of their soluble derivatives, while lignin remained insoluble. The residue is called Klason lignin and is determined as a percentage of the absolute dry mass of the wood used, according to ASTM D1106-96, in dry and free of extracts wood (extraction with $95 \%$ ethyl alcohol, extraction with alcohol-toluene mixture 1: $2 \mathrm{v} / \mathrm{v}$ and extraction with hot water at $100^{\circ} \mathrm{C}$ ). At least two replicates were used for each type of material and the mean values were calculated.

\subsection{Microscopic observation of cell structure \\ 2.5. Mikroskopsko promatranje stanične strukture}

The wood anatomy was examined using a SEM, Scanning Electron Microscope S-3400N (Hitachi, Japan), as well as an electronic stereomicroscope, Nikon SMZ800 (Nikon Instruments Inc., Japan), in which $\mathrm{X} 16$ analysis was selected.

\subsection{Statistical analysis}

SPSS Statistics PASW 18 statistical package was used for the statistical analysis and appliance of oneway analysis of variance (ANOVA) of the recorded values $(p \leq 0.05)$ for the evaluation of the importance of differences between the experimental groups.

\section{RESULTS AND DISCUSSION}

\section{REZULTATI I RASPRAVA}

\subsection{FT-IR analysis}

\subsection{FT-IR analiza}

As evidenced by the images of thermally modified and unmodified poplar and black pine wood powder obtained by infrared IR spectroscopy, there are no 
Table 1 Match of wood functional groups to IR bands of spectra (Bodirlau and Teaca, 2009; Esteves et al., 2013)

Tablica 1. Povezanost funkcionalnih skupina drva s vrpcama na IR spektru (Bodirlau and Teaca, 2009.; Esteves et al., 2013.)

\begin{tabular}{|c|c|c|}
\hline $\begin{array}{l}\text { Spectrum band position, } \mathbf{c m}^{-1} \\
\text { Pozicija vrpce na spektru, } \mathrm{cm}^{-1}\end{array}$ & $\begin{array}{c}\text { Active wood mass group } \\
\text { Aktivna grupa } u d r v u \\
\end{array}$ & $\begin{array}{c}\text { Type of vibration } \\
\text { Vrsta vibracije }\end{array}$ \\
\hline $3450-3400$ & $\mathrm{O}-\mathrm{H}$ of alcohols, phenols and acids & $\mathrm{O}-\mathrm{H}$ stretching \\
\hline $2970-2850$ & $\mathrm{CH}_{2}, \mathrm{CH}-$ and $\mathrm{CH}_{3}$ & C-H stretching \\
\hline $1750-1720$ & $\begin{array}{l}\mathrm{C}=\mathrm{O} \text { of esters, ketones, aldehydes } \\
\text { and acids }\end{array}$ & $\mathrm{C}=\mathrm{O}$ stretching, non-conjugated \\
\hline $1700-1550$ & Conjugated $\mathrm{C}=\mathrm{O}$ and $\mathrm{C}=\mathrm{C}$ & Conjugated $\mathrm{C}=\mathrm{O}$ stretching, $\mathrm{C}=\mathrm{C}$ stretching \\
\hline $1640-1618$ & $\mathrm{C}=\mathrm{C}$ alkene & $\mathrm{C}=\mathrm{C}$ stretching \\
\hline $1600-1504$ & Aromatic ring $\mathrm{C}=\mathrm{C}$ & Benzene ring stretching vibrations \\
\hline $1462-1425$ & $\mathrm{CH}_{2}$ cellulose, lignin & C-H deformations \\
\hline 1420 & Aromatic ring and $\mathrm{CH}$ & Benzene skeletal combined with $\mathrm{C}-\mathrm{H}$ deformations \\
\hline $1384-1346$ & C-H cellulose, hemicellulose & \\
\hline $1330-1240$ & Lignin $\mathrm{S}$ and $\mathrm{G}$ units and $\mathrm{OH}$ & $\begin{array}{l}\mathrm{C}-\mathrm{O} \text { stretching and bending } \mathrm{OH} \text { antisymmetric } \\
\text { stretching vibration of the acetyl ester groups }\end{array}$ \\
\hline 1140 & G-Guaiacyl lignin and $\mathrm{C}-\mathrm{O}$ & $\mathrm{C}-\mathrm{H}$ deformations in $\mathrm{G}$ lignin and $\mathrm{C}-\mathrm{O}$ stretching \\
\hline 1128 & S-Syringyl lignin and $\mathrm{C}-\mathrm{O}$ & $\mathrm{C}-\mathrm{H}$ deformations in $\mathrm{S}$ lignin and $\mathrm{C}-\mathrm{O}$ stretching \\
\hline $1035-1025$ & $\mathrm{C}-\mathrm{O}-\mathrm{C}$ & Deformation \\
\hline 897 & $\begin{array}{l}\text { Anti-symmetric out-of-phase } \\
\text { stretching in pyranose ring }\end{array}$ & Stretching in pyranose ring \\
\hline
\end{tabular}

particular differences in anatomy, chemical bonds and the structure between the treated and untreated poplar (Figure 1,2) and pine (Figure 4), nor between the two species. In the spectra of poplar and pine controls, the spectral line and peaks are quite common, revealing that the types of wood bonds are similar between species and that wood carries the same functional groups, which cause different kinds of vibrations when the light bundle falls onto the sample.

The evaluation of spectra, in order to draw conclusions, was conducted using identification tables of the different bands corresponding to different characteristics of wood groups (Table 1), such as for example hydroxyl groups, carbon chains, carbonyls, double bonds and absorbed water, aromatic rings, etc.

Although the table is quite analytical, the differences between spectra of modified and unmodified wood are difficult to be identified, and even more complicated to be evaluated, since in wood mass a large number of reactions occur at the same time. Frequently, the creation of solution and bonds take place simultaneously, and consequently the reactions cannot be distinguished due to the complexity of the characteristics of the wood during its thermal treatment. A typical example of this is the increase in carbonyls $(\mathrm{C}=\mathrm{O})$ of hemicelluloses in the spectrum band of $1700 \mathrm{~cm}^{-1}-1730 \mathrm{~cm}^{-1}$

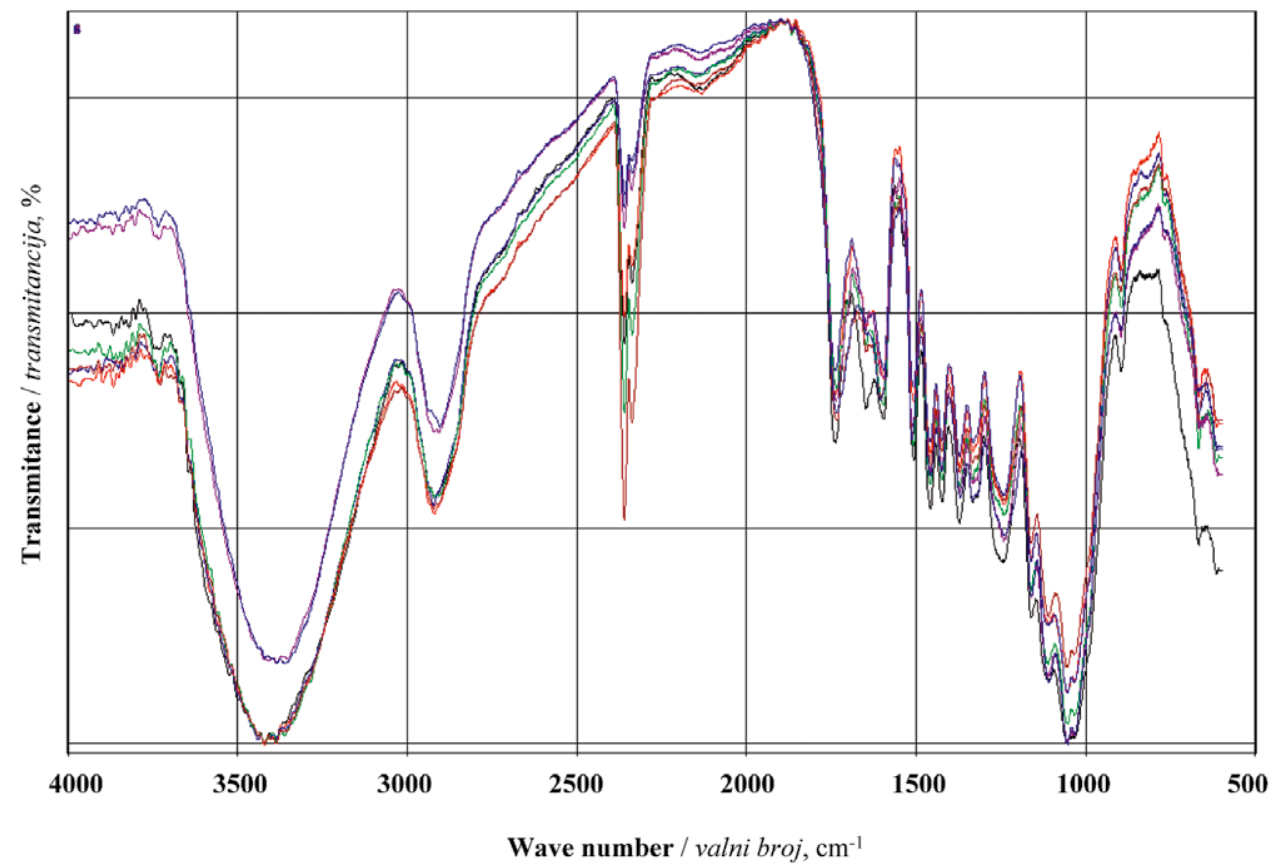

Figure 1 Overlapping IR spectra of a control (black line) and samples thermally modified with six different treatments (colored lines) of poplar over a range of $4000 \mathrm{~cm}^{-1}-500 \mathrm{~cm}^{-1}$

Slika 1. Preklapajući IR spektri kontrolnih uzoraka (crna linija) i toplinski modificiranih uzoraka tijekom šest različitih tretmana (obojene linije) drva topole u rasponu od $4000 \mathrm{~cm}^{-1}$ do $500 \mathrm{~cm}^{-1}$ 


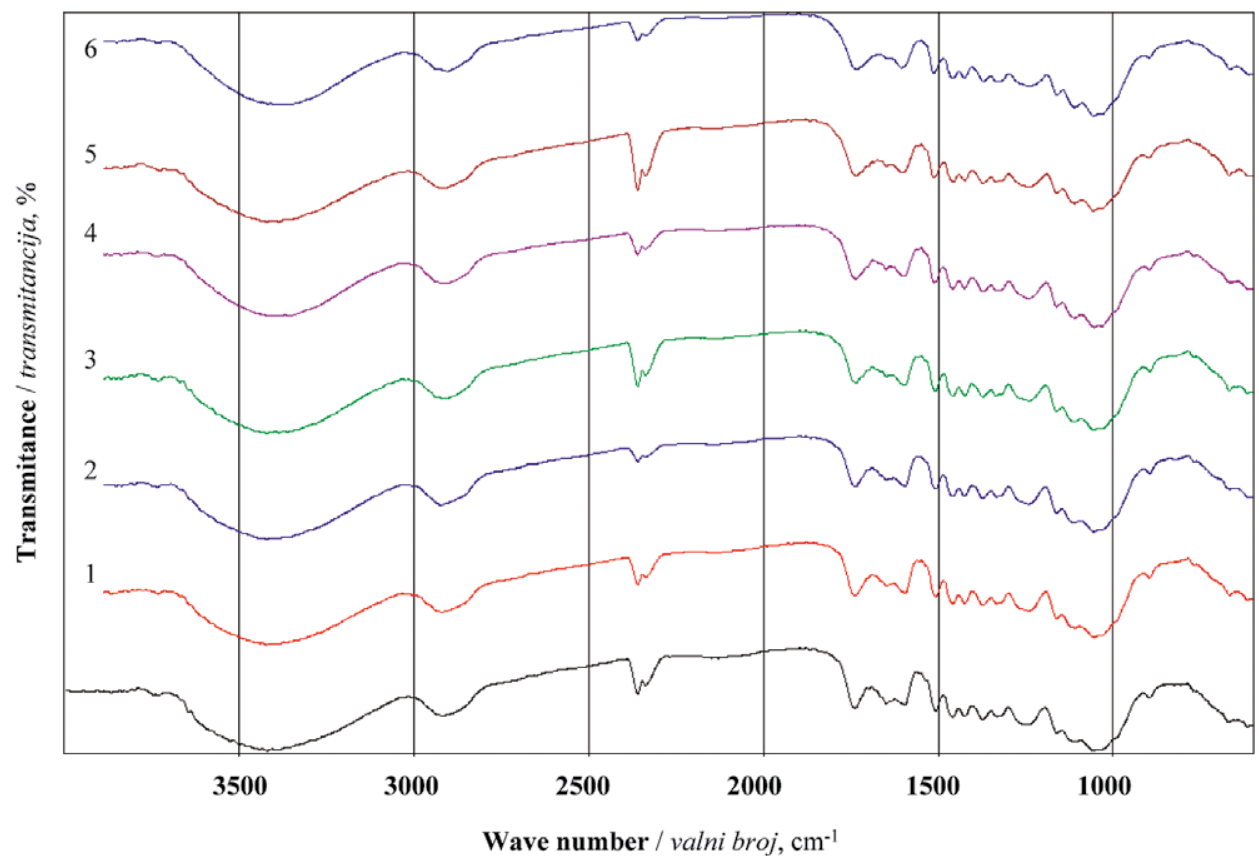

Figure 2 FT-IR spectral analysis of control specimens (black line) and samples heat-modified with six different treatments (1: $180{ }^{\circ} \mathrm{C}-3 \mathrm{~h}, 2: 180^{\circ} \mathrm{C}-5 \mathrm{~h}, 3: 180^{\circ} \mathrm{C}-7 \mathrm{~h}, 4: 200^{\circ} \mathrm{C}-3 \mathrm{~h}, 5: 200{ }^{\circ} \mathrm{C}-5 \mathrm{~h}, 6: 200{ }^{\circ} \mathrm{C}-7 \mathrm{~h}$ ) of poplar over a range of $4000-500 \mathrm{~cm}^{-1}$

Slika 2. Spektralna FT-IR analiza kontrolnih uzoraka (crna linija) i toplinski modificiranih uzoraka tijekom šest različitih tretmana $\left(1: 180{ }^{\circ} \mathrm{C}-3 \mathrm{~h}, 2: 180^{\circ} \mathrm{C}-5 \mathrm{~h}, 3: 180^{\circ} \mathrm{C}-7 \mathrm{~h}, 4: 200^{\circ} \mathrm{C}-3 \mathrm{~h}, 5: 200{ }^{\circ} \mathrm{C}-5 \mathrm{~h}, 6: 200{ }^{\circ} \mathrm{C}-7 \mathrm{~h}\right)$ drva topole u rasponu od $4000 \mathrm{~cm}^{-1}$ do $500 \mathrm{~cm}^{-1}$

and the simultaneous reduction of $\mathrm{C}=\mathrm{O}$ of lignin, which applies to both species of wood examined. However, some differences have emerged from the evaluation of the spectra, which are discussed below.

Referring to poplar wood, in the range of 1462 $\mathrm{cm}^{-1}-1425 \mathrm{~cm}^{-1}$ and $1384 \mathrm{~cm}^{-1}-1346 \mathrm{~cm}^{-1}$, where the basic structural components, such as cellulose, hemi- celluloses and lignin are depicted, there is a small difference between unmodified and modified samples, which supports the view that thermal treatment affects the levels of wood components even in the mildest treatments. Therefore, all treatments caused small changes and shifts of the spectral lines in the areas of the wood components. More specifically, referring to

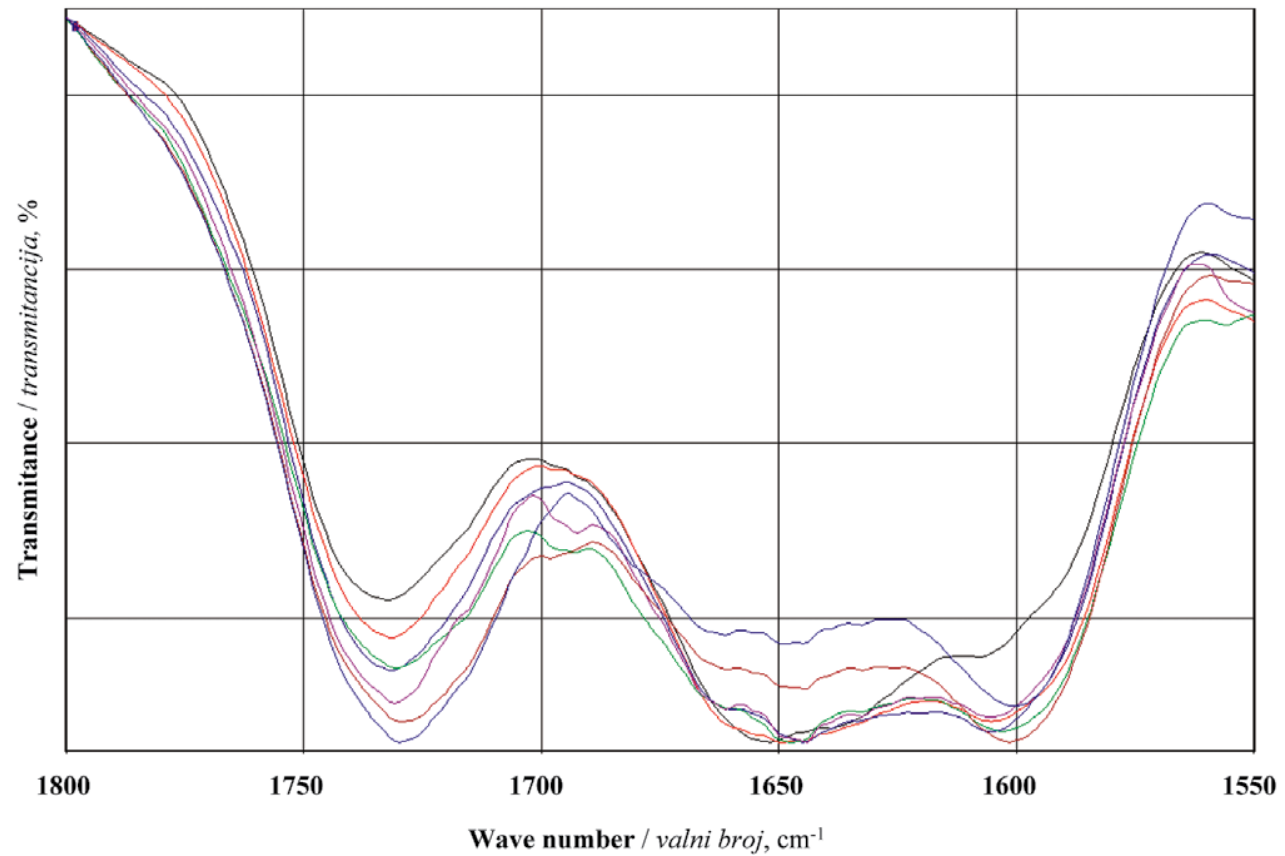

Figure 3 Overlapping IR spectra of control sample (black line) and heat-treated poplar samples with six different treatments (colored lines) over a range of $1800-1550 \mathrm{~cm}^{-1}$

Slika 3. Preklapanje IR spektra kontrolnih uzoraka (crna linija) i toplinski modificiranih uzoraka tijekom šest različitih tretmana (obojene linije) drva topole $u$ rasponu od $1800 \mathrm{~cm}^{-1}$ do $1550 \mathrm{~cm}^{-1}$ 
poplar wood, the data show that there was no major change in the $3430 \mathrm{~cm}^{-1}$ band, which corresponds to $\mathrm{O}-\mathrm{H}$ stretching vibrations of alcohols $\left(3600 \mathrm{~cm}^{-1}-3300\right.$ $\left.\mathrm{cm}^{-1}\right)$ and carboxylic acids $\left(3300 \mathrm{~cm}^{-1}-2500 \mathrm{~cm}^{-1}\right)$ and concerns equally polysaccharides and lignin. This phenomenon was expected, since even though the $\mathrm{O}-\mathrm{H}$ stretch vibrations due to the polysaccharides decrease, at the same time the $\mathrm{O}-\mathrm{H}$ vibrations derived from the phenolic groups of the lignin are increased due to the increase in the percentage of lignin in the mass of wood (Esteves et al., 2011). The spectra are normalized at about $1900 \mathrm{~cm}^{-1}$.

The two bands at $2900 \mathrm{~cm}^{-1}$ and $2800 \mathrm{~cm}^{-1}$ consist of the overlapping of the stretch asymmetric vibrations of the $-\mathrm{CH}_{2}$ - (around the $2935 \mathrm{~cm}^{-1}-2915 \mathrm{~cm}^{-1}$ band) and $-\mathrm{CH}_{3}$ (around the $2970 \mathrm{~cm}^{-1}-2950 \mathrm{~cm}^{-1}$ band), as well as of the overlapping of stretch symmetric vibrations of the $-\mathrm{CH}_{2}-\left(\right.$ about $2865 \mathrm{~cm}^{-1}-2845 \mathrm{~cm}^{-1}$ ) and $-\mathrm{CH}_{3}$ (about $2880 \mathrm{~cm}^{-1}-2860 \mathrm{~cm}^{-1}$ ). In these bands, a slight shift is detected.

In poplar wood, the area around $1750 \mathrm{~cm}^{-1}$ is not so clear, probably due to the normalization. In respective studies, e.g. Esteves et al. (2013), wood of thermally modified eucalyptus and pine initially decreased in this band in mild treatments, while increasing the treatment duration this band increased, recording a shift to lower wavelengths. The same happened here in the case of poplar, which recorded an increase and shifting in the band of $1730 \mathrm{~cm}^{-1}$. The increase and shifting for smaller wavenumbers with increasing treatment severity may be due to an increase of carbonyl or carboxyl groups in lignin or carbohydrates by oxidation. This increase was also observed by Koti- lainen et al. (2000) with Pinus sylvestris and Picea abies $\left(160{ }^{\circ} \mathrm{C}-260{ }^{\circ} \mathrm{C}, 2-8 \mathrm{~h}\right)$ and González-Peña et al. (2009) $\left(180{ }^{\circ} \mathrm{C}-245{ }^{\circ} \mathrm{C}\right)$ who attributed this increase to lignin condensation reactions at the expense of $\mathrm{C}=\mathrm{C}$ double bonds in conjugated carbonyl groups in lignin, vibrating at $1654 \mathrm{~cm}^{-1}$. The spectra of this research seem to corroborate this assumption since there was a clear decrease at $1654 \mathrm{~cm}^{-1}$ for both poplar and pine, while there was also some shifting to lower bands.

The band at $1595 \mathrm{~cm}^{-1}$ corresponds to vibrations in the aromatic ring of lignin in addition to $\mathrm{C}=\mathrm{O}$ stretching. The band at $1595 \mathrm{~cm}^{-1}$ showed a clear increase. According to Kotilainen et al. (2000), this band increases due to the increase in the lignin percentage and network through ramification in treated wood. The aromatic rings usually exhibit a characteristic band at approximately $1500 \mathrm{~cm}^{-1}$, corresponding to benzene ring stretching vibrations. This band is of high importance, since it is located at about $1505 \mathrm{~cm}^{-1}$ for hardwood lignin (Guaiacyl - G and Syringyl - S) and about at $1510 \mathrm{~cm}^{-1}$ for softwood lignin (guaiacyl - G) (Faix et al., 1990). In poplar, the band at $1505 \mathrm{~cm}-1$ was decreased, shifting the spectrum line approximately at $1512 \mathrm{~cm}^{-1}$. This may be attributed to the reduction of the lignin methoxyl groups, which would refer more to a softwood lignin (G-lignin) or to the loss of Syringyl units (S-lignin), since this monomer is generally less condensed with $\mathrm{C}-\mathrm{C}$ bonds than guaiacyl monomer lignin and is more prone to be released from the thermal degradation (Faix et al., 1990). The shift of this band is in agreement with the results of previous studies (Esteves and Pereira, 2008; Windeisen et al., 2007)

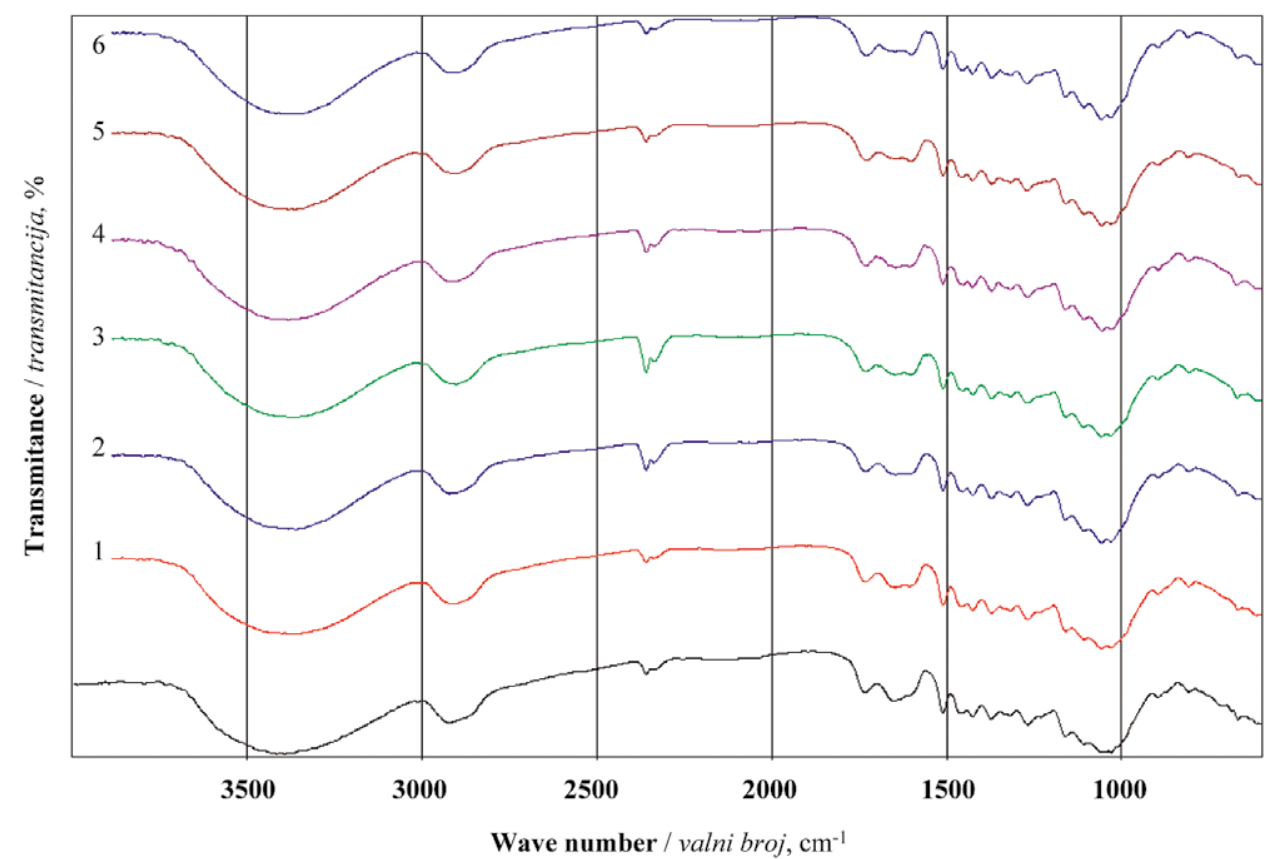

Figure 4 FT-IR spectral analysis of control specimens (black line) and samples heat-modified with six different treatments (1: $180^{\circ} \mathrm{C}-3 \mathrm{~h}, 2: 180^{\circ} \mathrm{C}-5 \mathrm{~h}, 3: 180^{\circ} \mathrm{C}-7 \mathrm{~h}, 4: 200{ }^{\circ} \mathrm{C}-3 \mathrm{~h}, 5: 200{ }^{\circ} \mathrm{C}-5 \mathrm{~h}, 6: 200^{\circ} \mathrm{C}-7 \mathrm{~h}$ ) of black pine over a range of $4000-500 \mathrm{~cm}^{-1}$

Slika 4. Spektralna FT-IR analiza kontrolnih uzoraka (crna linija) i toplinski modificiranih uzoraka tijekom šest različitih tretmana $\left(1: 180{ }^{\circ} \mathrm{C}-3 \mathrm{~h}, 2: 180{ }^{\circ} \mathrm{C}-5 \mathrm{~h}, 3: 180^{\circ} \mathrm{C}-7 \mathrm{~h}, 4: 200^{\circ} \mathrm{C}-3 \mathrm{~h}, 5: 200{ }^{\circ} \mathrm{C}-5 \mathrm{~h}, 6: 200{ }^{\circ} \mathrm{C}-7 \mathrm{~h}\right)$ drva crnog bora u rasponu od $4000 \mathrm{~cm}^{-1}$ do $500 \mathrm{~cm}^{-1}$ 


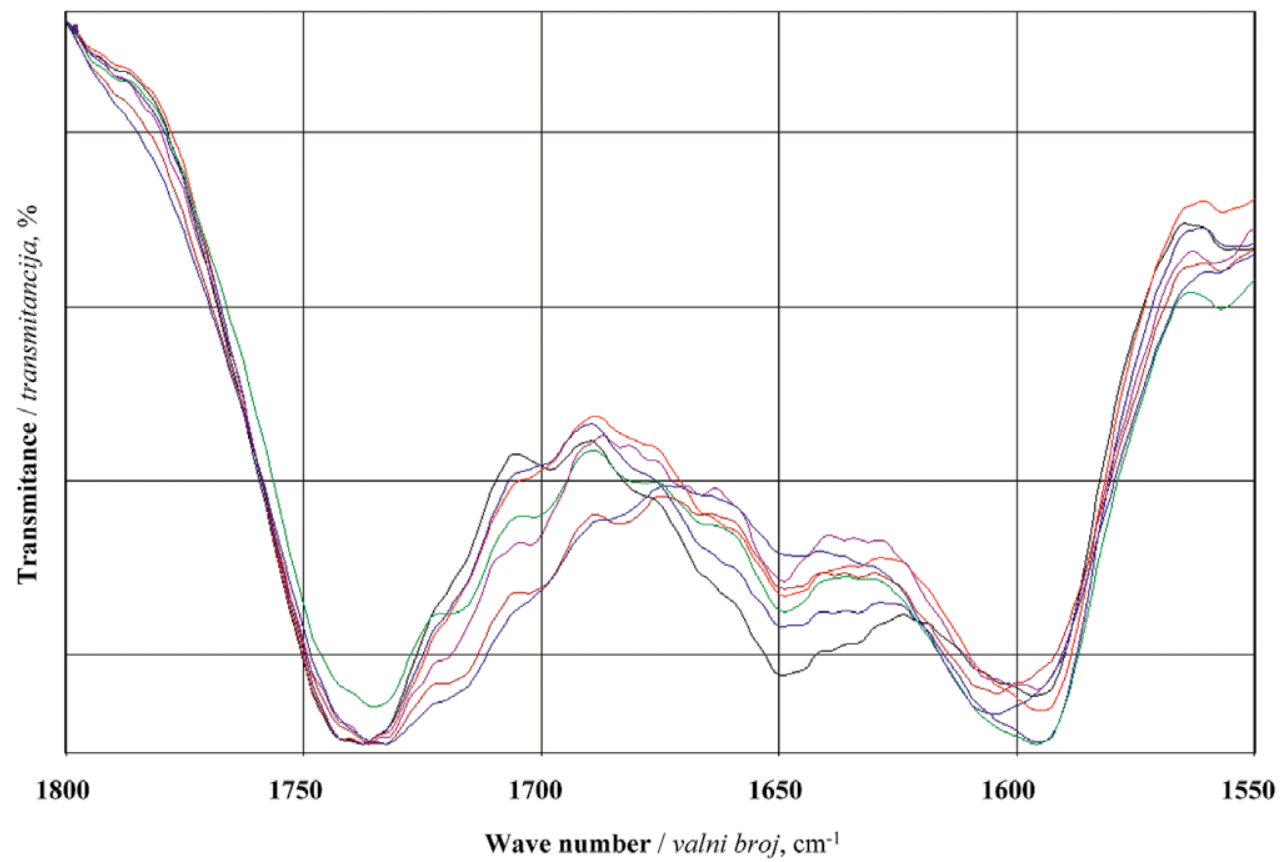

Figure 5 Overlapping IR spectra of control (black line) and thermally modified samples with six different treatments (color lines) of black pine in the range of $1800-1550 \mathrm{~cm}^{-1}$

Slika 5. Preklapanje IR spektra kontrolnog uzorka (crna linija) i toplinski modificiranih uzoraka tijekom šest različitih tretmana (obojene linije) drva crnog bora u rasponu od $1800 \mathrm{~cm}^{-1}$ do $1550 \mathrm{~cm}^{-1}$

and is attributable to the cleavage of the aliphatic side chains of lignin and the condensation reactions.

In addition, no significant variation was found in the spectra for peaks at $1460 \mathrm{~cm}^{-1}$ and $1420 \mathrm{~cm}^{-1}$. According to Kotilainen et al. (2000) and Weiland and Guyonnet (2003), the absorption peaks located at 1460 $\mathrm{cm}^{-1}$ and $1420 \mathrm{~cm}^{-1}$ increase with heat treatment. The band at $1375 \mathrm{~cm}^{-1}$ was broadened to lower wavenumbers, but without marking consistent variance. The band at $1333 \mathrm{~cm}^{-1}$ represents the contribution of all the structural components of wood, since it corresponds to the bending of the $\mathrm{C}-\mathrm{H}$ bending of polysaccharides, which joins the band at $1327 \mathrm{~cm}^{-1}$ of $\mathrm{S}$ and $\mathrm{G}$ lignin condensed units (Faix et al., 1990). There was also a clear increase at $1330 \mathrm{~cm}^{-1}$, which corresponds to the increase of lignin condensation. A similar tendency was reported by Windeisen et al. (2007).

As regards the black pine wood, the spectra band of $1800 \mathrm{~cm}^{-1}-1550 \mathrm{~cm}^{-1}$ and more particularly the 1600 $\mathrm{cm}^{-1}-1750 \mathrm{~cm}^{-1}$ revealed some differences between the $\mathrm{C}=\mathrm{O}$ bonds of carbonyls and $\mathrm{C}=\mathrm{C}$ bonds of alkenes of thermally modified and unmodified samples.

In the range of $1462 \mathrm{~cm}^{-1}-1425 \mathrm{~cm}^{-1}$ and 1384 $\mathrm{cm}^{-1}-1346 \mathrm{~cm}^{-1}$, where the basic structural components of wood are depicted, a small difference is found between unmodified and modified pine specimens, as in the case of poplar, which reinforces the view that the thermal treatment affects the levels of these components. The hemicelluloses, degraded due to thermal treatment, exhibit the decrease observed at $1730 \mathrm{~cm}^{-1}$. Lignin demonstrated some changes $\left(1505 \mathrm{~cm}^{-1}-1512\right.$ $\mathrm{cm}^{-1}$ ) probably attributed to a reduction in the methoxyl groups, the loss of syringyl units or the aliphatic side chain cleavage, with the parallel increase of the mass loss during treatment. Particularly, there was no major change in the $3430 \mathrm{~cm}^{-1}$ band, which corresponds to $\mathrm{O}-\mathrm{H}$ stretching vibrations of alcohols $\left(3600 \mathrm{~cm}^{-1}-3300\right.$ $\left.\mathrm{cm}^{-1}\right)$ and carboxylic acids $\left(3300 \mathrm{~cm}^{-1}-2500 \mathrm{~cm}^{-1}\right)$, concerning equally polysaccharides and lignin. The two bands at $2900 \mathrm{~cm}^{-1}-2800 \mathrm{~cm}^{-1}$ consist of the overlapping of the asymmetric vibration stretches of the $-\mathrm{CH}_{2}$ - (around the $2935 \mathrm{~cm}^{-1}-2915 \mathrm{~cm}^{-1}$ band) and the $-\mathrm{CH}_{3}$ (around the $2970 \mathrm{~cm}^{-1}-2950 \mathrm{~cm}^{-1}$ band), as well as of the overlapping of the asymmetric vibrations of the $-\mathrm{CH}_{2}$ - (about $2865 \mathrm{~cm}^{-1}-2845 \mathrm{~cm}^{-1}$ ) and the $-\mathrm{CH}_{3}$ (around the $2880 \mathrm{~cm}^{-1}-2860 \mathrm{~cm}^{-1}$ band), whereas in these bands a faint shift is also recorded in the species of pine.

In the area around $1750 \mathrm{~cm}^{-1}$, a clear increase is detected and, as also mentioned by Esteves et al. (2007), by increasing the treatment duration, this band tends to increase, recording a shift to lower wavenumbers. The same happened in this case with the observed increase and displacement in the zone of about 1730 $\mathrm{cm}^{-1}$. The spectra also revealed a clear decrease at 1654 $\mathrm{cm}^{-1}$, as in the case of poplar, marking a slight shift to lower bands.

The band point of $1595 \mathrm{~cm}^{-1}$, which corresponds to stretching vibrations in the aromatic ring of $\mathrm{C}=\mathrm{O}$, appears to be increased only in the milder treatment, while it was subsequently decreased in more intensive treatments due to the increase in the lignin percentage of heat treated wood. The aromatic rings most often exhibit a characteristic band at a point of about 1500 $\mathrm{cm}^{-1}$, corresponding to stretching vibrations of the benzene rings. Also in the case of pine, a shift of the band at the point of $1505 \mathrm{~cm}^{-1}$ was detected, probably attributed to the condensation reactions and the cleavage of the aliphatic side chains in lignin. In addition, a clear increase at $1330 \mathrm{~cm}^{-1}$ corresponding to an increase in 
lignin condensation was also detected in the case of black pine.

\subsection{Wet chemical analysis}

The results of the wet chemical analyses revealed changes in the content of wood components due to the influence of the treatments. Modified poplar wood revealed an intense reduction in the extractives percentage compared to unmodified wood, especially in short treatments ( 3 hours), a tendency recorded at both $180^{\circ} \mathrm{C}$ and $200{ }^{\circ} \mathrm{C}$ temperature levels, while increasing the duration, the percentage of extracts increased again with the most noticeable increase to be detected in the treatment at 180 ${ }^{\circ} \mathrm{C}-7$ hours. Based on the results (Figure 6), a reduction of $73.36 \%, 42.13 \%$ and $23.85 .43 \%$ was observed in material treated at $180{ }^{\circ} \mathrm{C}$ for 3,5 and 7 hours, respectively, while treatments at $200{ }^{\circ} \mathrm{C}(3,5$ and $7 \mathrm{~h})$ caused an extracts decrease of $65.21 \%, 37.27 \%$ and $13.27 \%$, respectively, compared to control. The extracts rate progress indicates that in the early stages of treatment, the volatile extracts are volatilized and some nonvolatile extracts are decomposed, resulting in an intense drop, while as the treatment time passes, new extracts (derivatives of hemicelluloses and lignin degradation) appear to be composed, which may also contribute to the darkening of wood color (Sahin et al., 2011; Kamperidou and Barboutis, 2018; Výbohová et al., 2018).

The lignin percent did not exhibit pronounced changes due to the treatment. Specifically, it presented a statistically insignificant decrease in the mildest treatment $\left(180^{\circ} \mathrm{C}-3 \mathrm{~h}\right)$ of $6.66 \%$, while it increased as the treatment intensity increased (by $0.81 \%$ at $180{ }^{\circ} \mathrm{C}$ $5 \mathrm{~h}, 7.65 \%$ at $180{ }^{\circ} \mathrm{C}-7 \mathrm{~h}$ and by $9.62 \%$ at $200{ }^{\circ} \mathrm{C}-3$ h, $9.87 \%$ at $200{ }^{\circ} \mathrm{C}-5 \mathrm{~h}$ and $10.31 \%$ at $200{ }^{\circ} \mathrm{C}-7 \mathrm{~h}$, respectively), with only the treatments at $200{ }^{\circ} \mathrm{C}$ to induce statistically significant differences in lignin content, compared to control values. This tendency could be attributed to the fact that the degradation products of carbohydrates, such as aldehydes, are condensed with lignin and other phenolic compounds (Yildiz et al., 2006; Esteves et al., 2013).
An insignificant decrease in the holocellulose $(2.64 \%)$ was noted in the milder treatment $\left(180^{\circ} \mathrm{C}-3\right.$ $\mathrm{h}$ ), as expected, because of the thermal decomposition of hemicelluloses, while as the duration reached the 7 hours, the percentage of holocellulose increased up to $31.16 \%$, which means that hemicelluloses decomposition produced derivatives that may have been re-polymerized in the cell wall, forming new complexes. Similar behavior was observed in the more intensive treatments at $200{ }^{\circ} \mathrm{C}$ for 3,5 and $7 \mathrm{~h}$, with the percentage of holocellulose increasing by $4.19 \%, 7.27 \%$ and $10.15 \%$, respectively.

In the case of black pine, a high decrease (78.7 $\%$ ) in the amount of extracts of the modified wood, especially in the material obtained from the mildest treatment $\left(180^{\circ} \mathrm{C}-3 \mathrm{~h}\right)$, as well as the subsequent treatments at $180{ }^{\circ} \mathrm{C}$ for 5 and $7 \mathrm{~h}$ (decrease of $64.76 \%$ and $55.13 \%$ ) and $200{ }^{\circ} \mathrm{C}$ for 3,5 and $7 \mathrm{~h}$ caused an extract decrease of $51.98 \%, 18.41 \%$ and $16.34 \%$ compared to the unmodified wood (Figure 7). Also, in the case of pine, extracts acted similarly as those of poplar, which suggests that in the early stages of treatment the extracts are reduced, while as long as the treatment duration increases, new extracts are formed as a result of the procedures taking place in the wood mass.

The lignin content showed a more pronounced increase after treatment compared to poplar wood. Specifically, the treatments at $180{ }^{\circ} \mathrm{C}$ for 3,5 and 7 hours caused an increase in the lignin content of pine wood by $2.94 \%, 11.66 \%$ and $23.14 \%$, respectively, while the treatments at $200{ }^{\circ} \mathrm{C}(3,5$ and $7 \mathrm{~h})$ caused an increase of $27.85 \%, 36.05 \%$ and $45.02 \%$, respectively. Therefore, as the intensity of treatment increases, the lignin is also increased, which clearly explains the intense change in color of wood and partly its behavior and mechanical performance.

The holocellulose content was found to be lower than that of control in all treatments due to the intense thermal degradation of hemicelluloses. Holocellulose levels were decreased by $29.52 \%, 28.64 \%$ and 19.87 $\%$ in the treatments at $180{ }^{\circ} \mathrm{C}$ for 3,5 and 7 hours, respectively. The treatments at $200{ }^{\circ} \mathrm{C}(3,5$ and $7 \mathrm{~h})$, re-

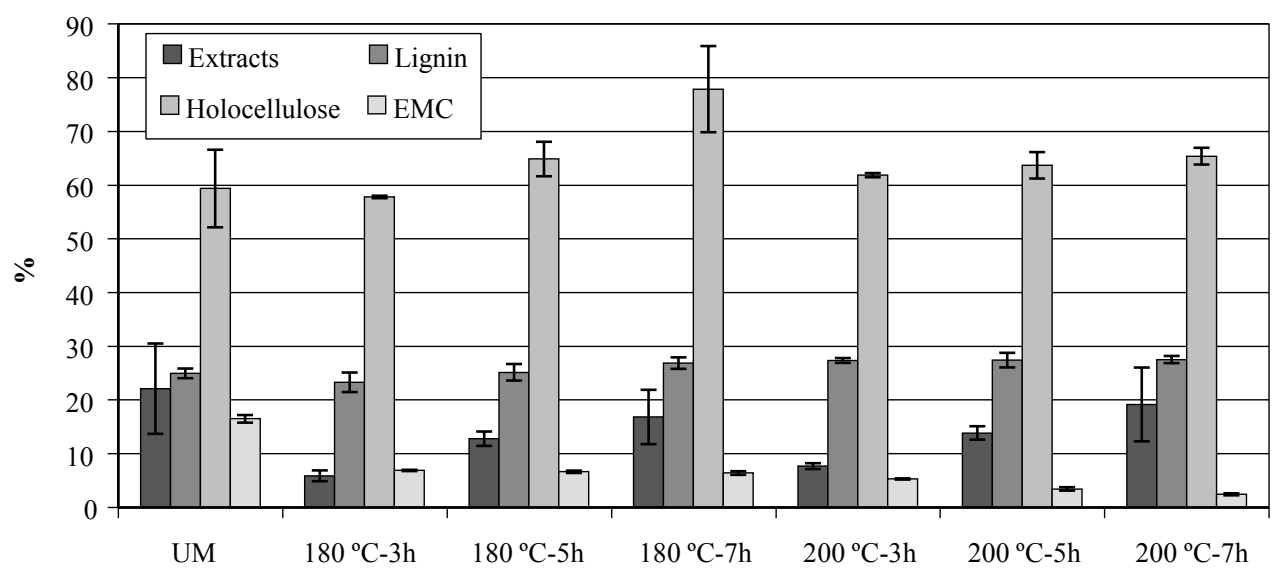

Figure 6 Mean values of chemical components content and equilibrium moisture content $(E M C$ - measured after conditioning) of unmodified and modified poplar wood

Slika 6. Srednje vrijednosti udjela kemijskih komponenata i ravnotežni sadržaj vode $(E M C$ - izmjeren nakon kondicioniranja) za nemodificirano i modificirano drvo topole 


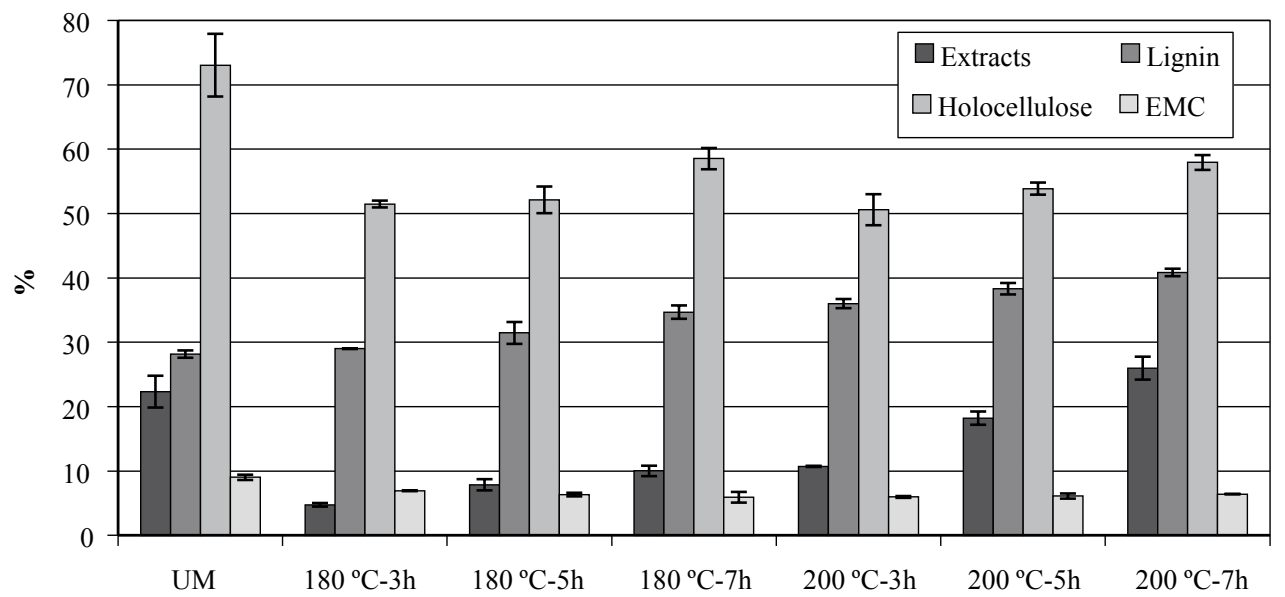

Figure 7 Mean values of chemical components content and equilibrium moisture content $(E M C$ - measured after conditioning) of unmodified and modified black pine wood

Slika 7. Srednje vrijednosti udjela kemijskih komponenata i ravnotežni sadržaj vode $(E M C$ - izmjeren nakon kondicioniranja) za nemodificirano i modificirano drvo crnoga bora

corded holocellulose reduction of $30.73 \%, 26.24 \%$ and $20.69 \%$, respectively, compared to the unmodified wood. The course of the holocellulose rate indicates that, in shorter and milder treatments, it decreases abruptly due to the decomposition of hemicelluloses and amorphous cellulose parts. Although increasing the treatment duration, an increase is recorded due to the re-polymerization of some thermo-degradation products, without however reaching the corresponding value of the control. Mburu et al. (2007) and Ates et al. (2010) also recorded a lignin increase after treatment and its ramification was detected above $200{ }^{\circ} \mathrm{C}$.

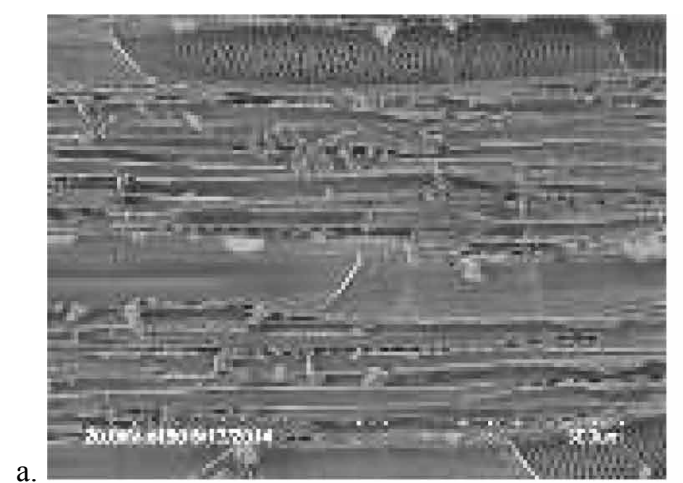

a.

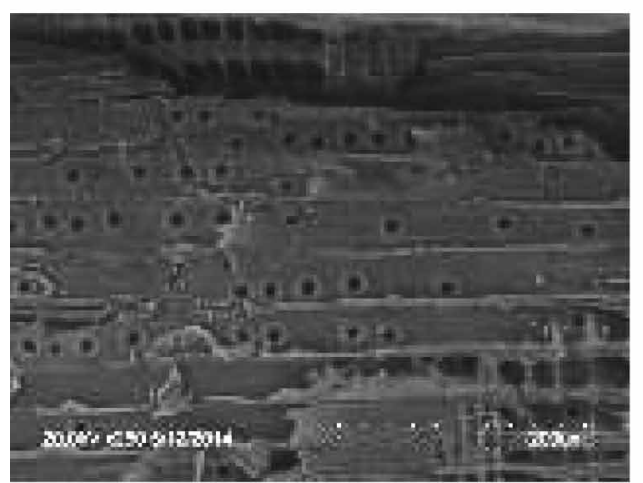

Parysek and Zakrzewski (2008) recorded a $32 \%$ reduction in the percentage of substances soluble to $1 \%$ $\mathrm{NaOH}$ of thermally modified Scots pine, $62 \%$ decrease in the substances soluble to $2 \% \mathrm{HCl}$ and reduction in the ratio of low-molecular-weight hydrocarbons in the wood mass, whereas Bächle et al. (2007) noticed an increase in the extracts and a decrease in $\mathrm{pH}$ of thermally treated wood. Some of the studies identified in the literature (Bächle et al. 2007; Brito et al., 2008; Rowell et al., 2009; Akgul and Korkut, 2012; Burgos and Rolleri, 2012; Wang et al., 2018) present findings that seem to be in agreement with the results of the current research work.
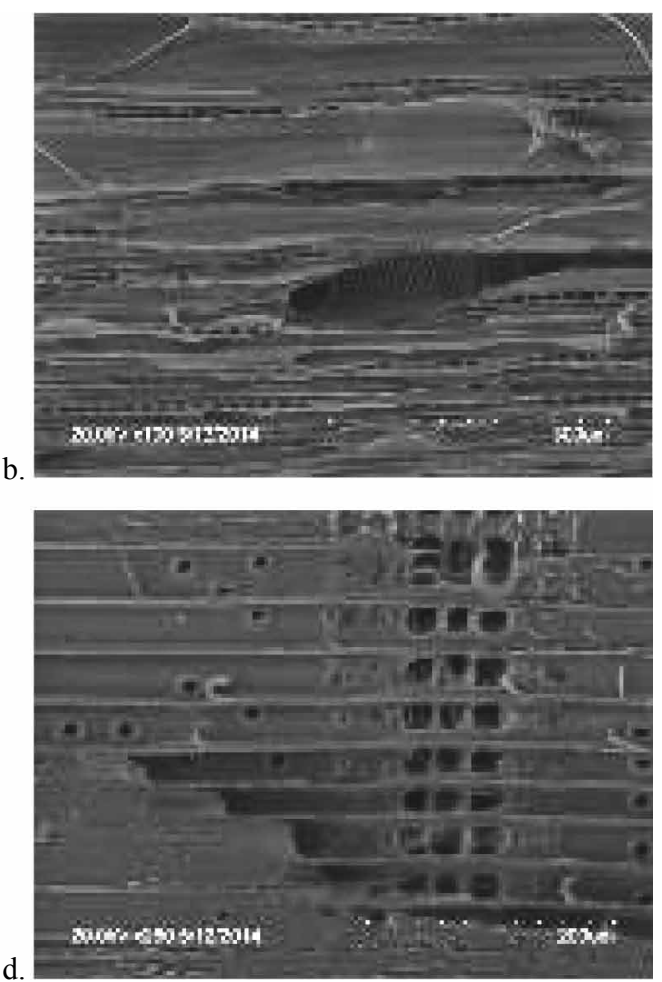

Figure 8 SEM micrographs of tangential view of a poplar control (a), tangential view of modified $\left(200{ }^{\circ} \mathrm{C}-7 \mathrm{~h}\right)$ poplar (b), radial view of black pine control (c), radial view of modified $\left(200^{\circ} \mathrm{C}-7 \mathrm{~h}\right)$ pine (d) using scanning electron microscopy Slika 8. SEM mikrografije tangentnog presjeka kontrolnog uzorka drva topole (a), tangentnog presjeka modificiranog $\left(200^{\circ} \mathrm{C}\right.$ - 7h) drva topole (b), radijalnog presjeka kontrolnog uzorka drva crnog bora (c), radijalnog presjeka modificiranog $\left(200^{\circ} \mathrm{C}-\right.$ 7h) drva crnog bora (d) 


\subsection{Microscopic observation of cell structure}

3.3. Mikroskopska analiza strukture stanica

In the images obtained using a stereomicroscope, as well as a SEM microscope, differences do not appear to be apparent between the appearance of untreated and treated wood cells referring both to poplar and black pine wood (Figure 8). The thermal degradation, usually occurring during treatments, did not cause cracks or could have caused some microcracks in the membranes of pits or at points of the secondary cell wall, which are however very difficult to be detected. Even though high temperatures were used in this experimental work, the thermo-degradation caused by the thermal treatments was not found to be intense, since the temperature alone is not able to cause changes in wood components, but it does in combination with other factors, such as the duration, atmosphere, moisture content, potential pressure, etc. (Garcia et al., 2010).

\section{CONCLUSIONS}

4. ZAKLJUČAK

FTIR spectroscopy in combination with wet chemical analysis proved to be a practical method that could be used in the characterization of thermally treated wood. Various changes and shifts in the FT-IR spectra lines of all the treated wood categories revealed that the wood components have been considerably affected, even in the shortest treatments. The free hydroxyl groups were decreased, with the parallel degradation of hemicelluloses, and the cross-linking and ramification of lignin seem to increase due to condensation reactions, especially at $200{ }^{\circ} \mathrm{C}$. These changes in components are in agreement with the results obtained from the wet chemical analyses. In the early stages of thermal treatment, the extracts of pine exhibited a decrease (by $78.7 \%$ ), while as the duration and temperature of the treatment increased, new extracts were formed from the processes taking place in wood mass, approaching the extracts percent of unmodified wood. The lignin of pine revealed a pronounced increase after treatment, and it was higher and faster than the lignin increases of poplar. Specifically, the treatments of pine at $180{ }^{\circ} \mathrm{C}$ caused a lignin increase of $2.94 \%-23.14 \%$, while the treatments at $200{ }^{\circ} \mathrm{C}$ caused a much higher increase $(27.85 \%-45.02 \%)$. This increase could be attributed to the degradation products of carbohydrates that are condensed with lignin and other phenolic compounds and clearly explains the intense change in color and partly the mechanical performance of wood. The holocellulose in all treated samples was found lower than in the control, mainly because of the intense decomposition of hemicelluloses (19.87\% - 30.73\%).

Poplar wood components seem to be similarly affected by thermal treatment, with extracts reduced in the short treatments and increased again as the duration and temperature rise. Specifically, a reduction of 23.85 $\%-73.36 \%$ was recorded in poplar extracts at $180{ }^{\circ} \mathrm{C}$ treatments and $13.27 \%-65.21 \%$ at $200{ }^{\circ} \mathrm{C}$, compared to unmodified wood. Lignin was slightly increased in line with the treatment intensity increase. The holocel- lulose recorded an increase of $4.19 \%-10.15 \%$ as the duration and temperature increased, attributed probably to the repolymerization of the hemicelluloses decomposition derivatives in the cell walls, forming new complexes.

Generally, the short thermal modification process made wood materials of both species of lower EMC more hydrophobic, and therefore more dimensionally stable and protected against decomposing factors. At the same time, they are not intensively thermo-degraded by the treatment, according to FTIR and SEM findings, which is a fact that may increase their utilization perspectives and range of applications - as solid wood acquiring enhanced properties, or as wood particles/ fibers participating as raw materials in wood-based composite products, wood-polymers composites, etc. enhancing their properties and performance.

\section{Acknowledgements - Zahvala}

The author warmly thanks the team of the Wood science Institute in University of Sopron for the provision of SEM microscope, the Department of Chemistry in Poznan University for the provision of the spectrophotometer and the Wood Engineering Department of Polytechnik Institute of Viseu for the help in FT-IR spectra interpretation.

\section{REFERENCES}

\section{LITERATURA}

1. Ahajji, A.; Diouf, P. N.; Aloui, F.; Elbakali, I.; Perrin, D.; Merlin, A.; George, B., 2009: Influence of heat treatment on antioxidant properties and colour stability of beech and spruce wood and their extractives. Wood Science and Technology, 43: 69-83. https://doi.org/10.1007/s00226-008-0208-3.

2. Akgul, M.; Korkut, S., 2012: The effect of heat treatment on some chemical properties and colour in Scots pine and Uludağ fir wood. International Journal of Physical Sciences, 7 (21): 2854-2859. https://doi.org/10.5897/ijps12.281.

3. Ates, S.; Akyildiz, M. H.; Özdemir, H.; Gumuskaya, E., 2010: Technological and chemical properties of chestnut (Castanea sativa Mill.) wood after heat treatment. Romanian Biotechological Letters, 15 (1): 4949-4958.

4. Bächle, F.; Niemz, P.; Schneider, T., 2007: Physical-mechanical properties of hard- and softwood heat treated in an autoclave. In: Proceeding of $3^{\text {rd }}$ European Conference on Wood Modification, Cardiff, UK, 15-16 October, 177-182.

5. Bodirlau, R.; Teaca, C. A., 2009: Fourier transform infrared spectroscopy and thermal analysis of lignocellulose fillers treated with organic anhydrides. Romanian Journal of Physics, 54 (1-2): 93-104.

6. Brito, J. O.; Silva, F. G.; Lego, M. M.; Almeida, G., 2008: Chemical composition changes in eucalyptus and pinus woods submitted to heat treatment. Bioresources Technology, 99: 8545-8548.

https://doi.org/10.1016/j.biortech.2008.03.069.

7. Burgos, F.; Rolleri, A., 2012: Effect of hydro- and hygrothermal treatments on some wood properties of pinus radiata and pseudotsuga menziesii. Drvna industrija, 63 (3): 211-215. https://doi.org/10.5552/drind.2012.1133.

8. Diouf, P. N.; Stevanovic, T.; Cloutier, A.; Fang, C. H.; Blanchet, P.; Koubaa, A.; Mariotti, N., 2011: Effects of thermo-hygro-mechanical densification on the surface characteristics of trembling aspen and hybrid poplar 
wood veneers. Applied Surface Science, 257 (8): 35583564. https://doi.org/10.1016/j.apsusc.2010.11.074.

9. Esteves, B.; Pereira, H., 2008: Wood modification by heat treatment: a review. BioResources, 4 (1): 370-404. https://doi.org/10.15376/biores.4.1.370-404.

10. Esteves, B.; Velez Marques, A.; Domingos, I.; Pereira, H., 2007: Influence of steam heating on the properties of pine (Pinus pinaster) and eucalypt (Eucalyptus globulus) wood. Wood Science and Technology, 41: 193-207. https://doi.org/10.1007/s00226-006-0099-0.

11. Esteves, B.; Velez Marques, A.; Domingos, I.; Pereira, H., 2013: Chemical changes of heat treated pine and eucalypt wood monitored by FTIR. Maderas Ciencia y Tecnologia, 15 (2): 245-258. https://doi.org/10.4067/s0718$221 \times 2013005000020$.

12. Esteves, B.; Nunes, L.; Pereira, H., 2011: Properties of furfurylated wood (Pinus pinaster). European Journal of Wood and Wood Products, 69: 521-525. https://doi.org/10.1007/s00107-010-0480-4.

13. Faix, O.; Meier, D.; Fortmann, I., 1990: Thermal degradation products of wood. A collection of electron-impact (EI) mass spectra of monomeric lignin derived products. Holz als Roh- und Werkstoff, 48: 351-354. https://doi.org/10.1007/BF02639897.

14. Garcia, R. A.; de Carvalho, A. M.; Latorraca, J. V.; de Matos, J. M.; Santos, W. A.; De Medeiros Silva, R. F., 2010: Nondestructive evaluation of heat-treated Eucalyptus grandis Hill ex Maiden wood using stress wave method. Wood Science and Technology, 46: 41-52. https://doi.org/10.1007/s00226-010-0387-6.

15. Gonultas, O.; Candan, Z., 2018: Chemical characterization and FTIR spectroscopy of thermally compressed eucalyptus wood panels. Maderas Ciencia y Tecnologia, 20 (3): 431-442. https://doi.org/10.4067/S0718-221X2018005031301.

16. Gonzalez-Pena, M.; Curling, S.; Hale, M., 2009: On the effect of heat on the chemical composition and dimensions of thermally-modified wood. Polymer Degradation and Stability, 94: 2184-2193. https://doi.org/10.1016/j. polymdegradstab.2009.09.003.

17. Gündüz, G.; Aydemir, D., 2009: Some physical properties of heat-treated hornbeam (Carpinus betulus L.) Wood. Drying Technology, 27 (5): 714-720. https://doi.org/10.1080/07373930902827700.

18. Hill, C., 2006: Wood Modification, Chemical, Thermal and other processes. John Wiley \& Sons Ltd, The Átreium, Southern Gate, Chichester.

19. ***ISO 13061-1, 2014: Physical and mechanical properties of wood - Test methods for small clear wood specimens - Part 1: Determination of moisture content for physical and mechanical tests. ISO: Geneva, Switzerland, 2014.

20. Johansson, D., 2008: Heat treatment of solid wood effects on absorption, strength and colour. Doctoral Thesis, Luleå University of Technology, 53, pp.142.

21. Kamperidou, V., 2019: The biological durability of thermally- and chemically-modified black pine and poplar wood against basidiomycetes and mold action. Forests, 10 (12): 1111. https://doi.org/10.3390/f10121111

22. Kamperidou, V.; Barboutis, I., 2017: Mechanical strength and surface roughness of thermally modified poplar wood. PRO Ligno, 13: 107-114.

23. Kamperidou, V.; Barboutis, I., 2018: Changes in hygroscopic properties of poplar and black pine induced by thermal treatment. PRO Ligno, 14: 57-64.

24. Kocaefe, D.; Poncsak, S.; Boluk, Y., 2008: Effect of thermal treatment on the chemical composition and mechan- ical properties of birch and aspen. BioResources, 3 (2): 517-537.

25. Kol, H. S., 2010: Characteristics of heat-treated Turkish pine and fir wood after ThermoWood processing. Journal of Environmental Biology, 31 (6): 1007-1011.

26. Kotilainen, R.; Toivannen, T.; Alén, R., 2000: FTIR monitoring of chemical changes in softwood during heating. Journal of Wood Chemistry and Technology, 20 (3): 307320. https://doi.org/10.1080/02773810009349638.

27. Mazela, B.; Zakrzewski, R.; Grześkowiak, W.; Cofta, G.; Bartkowiak, M., 2004: Resistance of thermally modified wood to basidiomycetes. Electronic Journal of Polish Agricultural Universities. Series of Wood Technology, 7 (10): 253-262.

28. Mburu, F.; Dumarcay, S.; Huber, F.; Petrissans, M.; Gerardin, P., 2007: Evaluation of thermally modified Grevillea robusta heartwood as an alternative to shortage of wood resource in Kenya: Characterisation of physicochemical properties and improvement of bio-resistance. Bioresources Technology, 98: 3478-3486. https://doi.org/10.1016/j.biortech.2006.11.006.

29. Ozcifci, A.; Kokten, E. S.; Ayrilmis, N.; Özbay, G.; Altun, S., 2018: Effects of catalysts on modulus of rupture and chemical structure of heat-treated wood. Drvna industrija, 69 (3): 207-213. https://doi.org/10.5552/drind.2018.1717.

30. Parysek, M.; Zakrzewski, R., 2008: Investigations on the chemical composition of pine wood subjected to modification in the atmosphere of Nitrogen. Folia Forestalia Polonica, Ser B (39): 3-7.

31. Peters, J.; Fischer, K.; Fischer, S., 2008: Characterization of emissions from thermally modified wood and their reduction by chemical treatment. BioResources, 3 (2): 491502 .

32. Rowell, R. M.; Ibach, R. E.; McSweeny, J.; Nilsson, T., 2009: Understanding decay resistance, dimensional stability and strength changes in heat treated and acetylated wood. Material Science and Engineering, 4 (1-2): 14-22. https://doi.org/10.1080/17480270903261339.

33. Sahin, H. T.; Arslan, M. B.; Korkut, S.; Sahin, C., 2011: Colour changes of heat-treated woods of red-bud maple, European hophornbeam and oak. Color Research \& Application, 36 (6): 462-466.

https://doi.org/10.1002/col.20634.

34. Sahin, C.; Topay, M.; Var, A. A., 2020: A study on some wood species for landscape applications: Surface color, hardness and roughness changes at outdoor conditions. Wood Research, 65 (3): 395-404. https://doi.org/DOI: 10.37763/wr.1336-4561/65.3.395404.

35. Tjeerdsma, B. F.; Militz, H., 2005: Chemical changes in hydrothermal treated wood: FTIR analysis of combined hydrothermal and dry heat-treated wood. Holz als Roh und Werkstoff, 63: 102-111. https://doi.org/10.1007/s00107-004-0532-8.

36. Tumen, I.; Aydemir, D.; Gündüz, G.; Uner, B.; Cetin, H., 2010: Changes in the chemical structure of thermally treated wood. BioResources, 5 (3): 1936-1944.

37. Výbohová, E.; Kučerová, V.; Andor, T.; Balážová, Z.; Vel'ková, V., 2018: The effect of heat treatment on the chemical composition of ash wood. BioResources, 13 (4): 8394-8408. https://doi.org/10.15376/biores.13.4.8394-8408.

38. Wang, X.; Chen, X.; Xie, X.; Wu, Y.; Zhao, L.; Li, Y.; Wang, S., 2018: Effects of thermal modification on the physical, chemical and micromechanical properties of Masson pine wood (Pinus massoniana Lamb.). Holzforschung, 72 (12): 1063-1070. https://doi.org/10.1515/hf-2017-0205. 
39. Weiland, J.; Guyonnet, R., 2003: Study of chemical modifications and fungi degradation of thermally modified wood using DRIFT spectroscopy. Holz als Roh und Werkstoff, 61 (3): 216-220. https://doi.org/10.1007/s00107-003-0364-y.

40. Wikberg, H.; Maunu, S., 2004: Characterisation of thermally modified hard- and softwoods by $13 \mathrm{C}$ CPMAS NMR. Carbohydrate Polymers, 58: 461-466. https://doi.org/10.1016/j.carbpol.2004.08.008.

41. Windeisen, E.; Strobel, C.; Wegener, G., 2007: Chemical changes during the production of thermotreated beech wood. Wood Science and Technology, 41 (6): 523-536. https://link.springer.com/article/10.1007/s00226-0070146-5.

42. Yao, C.; Yongming, F.; Jianmin, G.; Houkun, L., 2010: Coloring characteristics of in situ lignin during heat treatment. Wood Science and Technology, 46 (1-3): 33-40. https://doi.org/10.1007/s00226-010-0388-5.

43. Yildiz, S.; Gezer, E.; Yildiz, U., 2006: Mechanical and chemical behavior of spruce wood modified by heat. Building and Environment, 41: 1762-1766. https://doi.org/10.1016/j.buildenv.2005.07.017.

44. Yildiz, S.; Gumuskaya, E., 2007: The effects of thermal modification on crystalline structure of cellulose in soft and hardwood. Building and Environment, 42: 62-67. https://doi.org/10.1016/j.buildenv.2005.07.009.

45. ***ASTM D1107-96, 2013: Standard Test Method for Ethanol-Toluene Solubility of Wood. ASTM International: West Conshohocken, PA, USA, 2013.
46. ***ASTM D1105-96, 2013: Standard Test Method for Preparation of Extractive-Free Wood. ASTM International: West Conshohocken, PA, USA, 2013.

47. ***ASTM D1106-96, 2013: Standard Test Method for Acid-Insoluble Lignin in Wood. ASTM International: West Conshohocken, PA, USA, 2013.

48. ***ISO 13061-2, 2014: Physical and mechanical properties of wood - Test methods for small clear wood specimens - Part 2: Determination of density for physical and mechanical tests. ISO: Geneva, Switzerland, 2014.

49. ***ISO 3129, 2012: Wood - Sampling methods and general requirements for physical and mechanical testing of small clear wood specimens. ISO: Geneva, Switzerland, 2014.

\section{Corresponding address:}

\section{KAMPERIDOU VASILIKI, PhD}

Aristotle University of Thessaloniki

Faculty of Forestry and Natural Environment

Department of Harvesting and Technology of Forest Products

54124 Thessaloniki, GREECE

e-mail: vkamperi@for.auth.gr 